\title{
Origens sociais, ascensão "profissional" e concepções de ciências sociais: Florestan Fernandes e Fernando Henrique Cardoso
}

Rodrigo da Rosa Bordignon ${ }^{1}$

\section{Resumo}

O presente artigo tem como problema central as relações entre origens sociais, modalidades e chances de ascensão "profissional" e concepções de ciências sociais. Trata-se da exploração de um conjunto de indicações derivadas de uma pesquisa realizada anteriormente e centrada nas relações entre trajetos sociais e profissionais e a reconversão de recursos em posições de "reconhecimento" e excelência "profissional". 0 objetivo mais geral do trabalho é discutir algumas questões analíticas acerca das relações entre origens sociais, ascensão "profissional" e expectativas de retribuição. A hipótese perseguida é que nessas relações, o descompasso entre a posição de origem e determinadas posições no trajeto está no centro dos tipos de investimentos na realização das carreiras.

Palavras-chave: origens sociais, ascensão "profissional”, Florestan Fernandes, Fernando Henrique Cardoso. 


\section{Social origins, "professional" ascension and Social Science's conceptions: Florestan Fernandes and Fernando Henrique Cardoso}

\section{Abstract}

The main discussion of this paper is focused on the relations between social origins, modalities and chances of "professional" ascension, and social science's conceptions. It covers the analysis of a variety of paths derived from an earlier research and centered on the relations between social and "professional" trajectories and the reconversion of resources in positions of acknowledgment and "professional" excellence. The work's general objective is to discuss some analytical questions about the relations between social origins, "professional" ascension, and retribution's expectations. The assumption pursued is that in these relations, the mismatch between the position of origin and certain positions in the trajectory is in the center of investment's types regarding the careers' achievement.

Key-words: social origins, "professional" ascension, Florestan Fernandes, Fernando Henrique Cardoso.

\section{Introdução}

Uma das questões centrais para o trabalho de pesquisa mais geral que está na base do presente texto refere-se às lógicas de produção de documentos destinados à consagração social e, particularmente, ao conjunto de mecanismos sociais nos quais está imersa a escolha daqueles dignos de nota e de eternização como figuras-síntese da história (BORDIGNON, 2010). 0 ponto de partida para a pesquisa desenvolvida anteriormente foi a pu- 
blicação de um conjunto de obras de consagração coletiva² destinadas a reconstituir a história de determinadas disciplinas a partir do depoimento daqueles definidos como os protagonistas do processo, indicando uma concepção específica de que o desenrolar da história se confunde com o desenrolar da vida de seus heróis. Tipo de produto gráfico destinado a apresentar os caminhos e estratégias para o que se julga e se propõe como sucesso (GRIJÓ, 2008, p. 90), a referência aos "grandes homens" do passado (ou do presente) e a sua respectiva "sacralização" por meio de sua "eternização" não legitima somente os indivíduos selecionados para a composição desses monumentos, mas todo o conjunto de práticas, recursos e lógicas de ação - juntamente com as filosofias sociais correspondentes - que respaldam essas histórias de "êxito".

Nesse sentido, essas publicações forjadas e carimbados pela empresa biográfica (Ibidem) constituem um material interessante a ser tomado como ponto de partida na apreensão dos trajetos que conduzem às posições de excelência em determinados espaços de atuação. A constituição da população analisada no trabalho de pesquisa do qual deriva o presente artigo foi composta pela lista de vinte e um cientistas sociais cujos depoimentos foram reunidos em uma obra intitulada Conversas com Sociólogos Brasileiros, publicada em 2006 e organizada por Elide Rugai Bastos, Fernando Abrucio, José Marcio Rego e Maria Rita Loureiro.

A primeira vista, a centralização da pesquisa em um grupo previamente definido pode parecer um empecilho para a apreensão das estruturas de capitais que estão na base das divisões entre aqueles que ocupam posições dominantes no interior do espaço disciplinar relativo às ciências sociais e os demais agentes 
em concorrência no interior desse. No entanto, essa estratégia permite tanto a reconstrução das redes de relações subjacentes aos recursos e títulos ostentados pelos currículos dos eleitos, quanto a identificação dos agentes que as centralizam. Ao mesmo tempo, como se mostrou profícuo, enquanto estratégia de pesquisa, o caráter fluído das redes personificadas exige atenção especial àqueles não incluídos no grupo inicial, mas que, de modo geral, aparecem recorrentemente nos depoimentos e reconstruções biográficas. Esse desdobramento metodológico implica no levantamento de fontes diversas acerca dos trajetos dos agentes em questão, daqueles referidos por esses e o cotejo desse conjunto de dados com os contextos sócio-históricos nos quais se desenvolvem os trajetos. De modo geral, as informações coletadas envolvem tanto modelos de apresentação de si mais burocráticos (factuais), quanto outros mais mundanos (centrados no "princípio da notabilidade") (COLLOVALD, 1988, p. 31). Isso implica na consideração da "história factual" e da relação que os agentes estabelecem com ela, ou seja, os modos de acionamento (ou negação) e as representações acerca dos recursos que compõe as trajetórias, o que torna possível a identificação de um núcleo duro de fatos constantemente retomados e em torno dos quais se constituem as representações de si e dos outros (POLLAK, 1986, p. 52).

Como as diferentes modalidades de apresentação de si correspondem a uma personificação das exigências inscritas nos modos específicos de interação em determinados espaços de atuação (COLLOVALD, 1988, p. 34), os produtos biográficos e autobiográficos tendem a reforçar as concepções sociais e políticas associadas a determinados princípios de excelência social, bem como a relação desses com a "figura" a ser legitimada (COLLOVALD, 1990, p. 883). De tal modo, essas narrativas obedecem às lógicas próprias de legitimação das posições ocupadas e conquistadas (ou perdidas), as quais são elaboradas retrospectivamente e em função de uma necessidade de coerência constituída por referência a um ponto específico dos trajetos sociais (BOUR- 
DIEU, 1996, p. 76). Nesse sentido, inclusive, essas comportam as próprias representações acerca das formas de ingresso em determinadas atividades, de acesso a determinadas posições ou de conquista de determinadas honrarias, as quais dependem da origem social e da posição ocupada na estrutura de concorrência dos espaços de atuação em pauta (NEVEU, 1992, p. 11-12). Portanto, o desenrolar dessas narrativas pressupõe a busca de sentido que depende tanto das relações que os agentes estabelecem com as formas oficiais e mais formalizadas de apresentação de si (curriculum), quanto da elaboração de certo tipo de teoria interessada do carisma centrada na identificação e veiculação da predestinação, normalmente associada a algum acontecimento marcante ou ato inaugural (DAMMAME, 1994, p. 185).

Todo o conjunto de indicações analíticas acerca das possibilidades (e dificuldades) de uso de fontes de informação destinadas à apresentação de si e/ou dos outros reside nas condições de objetivação de sujeitos classificantes, ou seja, na autonomia do espaço escolar e científico (BOURDIEU, 1994, p. 28). Sem essa condição, a negação do postulado do sentido da existência compartilhado por sujeito e objeto da biografia (o entrevistador $e$ o entrevistado) (BOURDIEU, 1996, p. 75) tende a parecer uma manipulação das opiniões ou uma inquisição grosseira, principalmente por categorias sociais que se reconhecem por sua singularidade ou ancoram sua legitimidade no "mérito" (PENNEF, 1994, p. 28). Inclusive, esses problemas levam à objetivação constante das próprias ciências sociais e a explicitação de seus limites, ou seja, levam ao reconhecimento de que o sentido da vida dos sujeitos é sempre irredutível e indecifrável, pertencendo ao registro dessas verdades últimas que não concernem mais às ciências sociais (CONINCK et GODARD, 1990, p. 51).

Um dos desdobramentos dessas questões é justamente a indicação da relação entre as concepções presentes na produção de biografias (individuais e coletivas) e aquelas vigentes nos trabalhos dedicados à história da ciência no Brasil. Ambos são 
constantemente atravessados por esforços de retomada de personalidades, fundação de linhagens e tentativas de atribuição de sentido a determinadas divisões, cujas consequências centrais são tomadas de posição que giram em torno de relações de reciprocidade e de pertencimento a grupos fundados na tradição, no reforço da memória e ancorados nos débitos decorrentes dessas relações (POLLAK, 1989, p. 10). 0 principal problema decorrente é que isso tem efeitos significativos na veiculação de determinadas concepções de ciência e de carreira e, particularmente, nas próprias condições de objetivação dessas lutas.

Nesse sentido, uma série de controvérsias marca o conjunto de análises dedicadas a dar conta dos intelectuais e da vida intelectual (MICELI, 1999, p. 110) e da reconstrução de tradições científicas por meio do tratamento das dimensões institucional e profissional da história dos cientistas e das Ciências Sociais no país (MICELI, 1989, p. 5-6). De modo geral, as disputas pela interpretação legítima se estruturam em torno de dois polos. Um deles é demarcado pela tentativa de diferenciação dos modos de tratamento de questões acerca do tema, as quais se dividem entre a "sociologia dos intelectuais" e o "pensamento social e político brasileiro", ambos com seus respectivos expoentes, centros de difusão e vinculações regionais. No outro extremo, se situam os esforços e tentativas destinadas a apontar falhas, inconsistências, ausências ou o "etnocentrismo" de certas pesquisas, numa tentativa de fazer reconhecer determinadas especificidades, centros e seus respectivos expoentes.

Há ainda outro espaço de produção vinculado àquilo que se pode definir como a história oficial das universidades e faculdades, geralmente patrocinadas pelas próprias instituições ou por aqueles interessados em dar existência a determinados fatos, ficando ao encargo de agentes dedicados a celebrar, legitimar ou justificar visões ou posições no jogo das disputas endógenas e/ou com grupos sociais ou instituições (GRIJÓ, 2005, p. 15-16). Desse modo, uma das dificuldades que se coloca na elaboração de pro- 
blemas de pesquisa sobre o tema é a escassez de trabalhos que possam servir de ponto de partida e, inclusive, de contraponto. Isso porque a própria literatura dedicada ao tema é, ao mesmo tempo, fonte de informação e objeto de estudo, o que leva a prestar atenção nas condições associadas ao modo de elaboração e de veiculação de princípios de classificação que fundamentam a definição da atividade intelectual e do fazer científico. Tendo isso em vista, antes de qualquer avanço, cabe ressaltar que o presente texto não pretende dar nenhum tipo de resposta a esse conjunto de desentendimentos e controvérsias, até mesmo porque, isso foge completamente aos limites e possibilidades de um artigo, exigindo uma atenção especial ao conjunto das disputas, das reivindicações e os princípios de legitimação acionados nas interpretações e contraposições, o que faz parte de um conjunto de preocupações presentes em uma pesquisa em andamento.

Partindo dessas indicações quanto às fontes de informações utilizadas no trabalho que está na origem da presente exposição, o problema abordado está centrado nas relações entre origens sociais, modalidades e chances de ascensão "profissional" e as concepções de ciências sociais. 0 objetivo mais geral do trabalho é discutir algumas questões analíticas acerca das relações entre origens sociais, ascensão "profissional" e expectativas de retribuição. Com base nisso, a hipótese central é que nessas relações, o descompasso entre a posição de origem e determinadas posições no trajeto está no centro dos tipos de investimentos na realização das carreiras e da relação que se estabelece com as posições. Além disso, as próprias condições sociais de adoção das distintas modalidades de investimentos estão associadas ao horizonte dos possíveis e ao conjunto dos recursos passíveis de serem mobilizados por diferentes agentes nas estratégias de ascensão "profissional" e social.

A construção dessa hipótese está associada à indicação de uma décalage entre a posição de origem e a posição social atual ou potencial, particularmente dentro do horizonte de possibilida- 
des que compõe determinados trajetos. Essa diferença entre as aspirações e a posição ocupada, está na origem das estratégias de investimento na manutenção ou modificação das posições sociais e decorre do conjunto de percepções e apreciações que dependem da trajetória passada e dos quadros de referência possíveis, ou seja, dos grupos que fornecem os signos concretos da posição e os deslocamentos no espaço (BOURDIEU, 1984, p. 14). Nesse sentido, as relações que os agentes estabelecem com a posição podem se expressar tanto diacronicamente, ou seja, por referência ao seu próprio passado, o qual pode englobar o grupo de origem, o grupo de pares da posição atual e as expectativas derivadas da posição de origem com seus devidos lucros materiais e simbólicos correspondentes; quanto sincronicamente, portanto, com relação aos outros grupos sociais em um momento específico de estruturação do espaço social.

Além disso, o princípio das diferenças entre os esquemas operatórios reside na trajetória, ou seja, as percepções e apreciações que os agentes operam em determinadas situações baseiam-se na síntese entre as experiências passadas e as experiências novas, de modo que os agentes tendem a aplicar esquemas de (auto) proteção ou de ataque que, em medidas variadas, estão vinculados às próprias expectativas de manutenção ou transformação das posições ocupadas (BOURDIEU, 2009, p. 90-91). No centro dessas questões estão as relações entre capitais herdados e capitais adquiridos e as possibilidades de que os primeiros sejam acionados a favor dos segundos, notadamente, como modo de maximização dos lucros. Isso porque, como trabalho acumulado (BOURDIEU, 1986), o capital incorporado está na base de todas as relações de afinidade e cooptação e, ao mesmo tempo, nas diferentes possibilidades de reconversão e de antecipação dos investimentos (BOURDIEU, 2007, p. 160).

Consequentemente, na análise das relações entre origens sociais, chances e modalidades de ascensão "profissional" (e social), não é possível apreender as lógicas associadas e os recursos passí- 
veis de ser mobilizados nessas lutas, sem levar em conta o conjunto das oportunidades que se configuram em determinados espaços de atuação e suas efetivas chances de mobilização por agentes situados em diferentes polos e posições sociais. Colocando de outro modo, o reforço ou relativa independência frente às posições conquistadas ou visadas depende das possibilidades efetivas de acesso a elas, dos significados que lhes são atribuídos e das redes de proteção ligadas as diferentes posições sociais de origem que estão na base de todas as audácias e investimentos (BOURDIEU, 2007, p. 95). Assim, devem-se levar em conta as relações entre origens e trajetos sociais e as estratégias de reprodução e reclassificação que se abrem dentro do horizonte dos possíveis, as quais estão associadas às diferentes fases de constituição desses trajetos e as respectivas condições sociais associadas (CORADINI, 2010, p. 456).

A análise dos deslocamentos, reconversões e adesões que compõem os trajetos dos vinte e um cientistas sociais que fizeram parte da população inicial tornou possível a identificação de dois momentos distintos no processo de estruturação das carreiras. 0 primeiro refere-se ao período pré-reforma universitária de 1968, no qual as redes se estruturavam a partir das relações de concorrência pelo acesso às cátedras ou as posições imediatamente inferiores (professores assistentes e auxiliares) na estrutura universitária, o que envolve uma multiplicidade de investimentos e deslocamentos. A partir da década de 1970, particularmente com a reforma universitária e expansão da pós-graduação, ocorre uma maior diversificação de trajetos "profissionais" e uma ampliação das redes de relações para uma multiplicidade de frentes que envolvem desde a ocupação de funções docentes, até a inserção na administração universitária, nas instituições de avaliação e fomento de ensino e pesquisa, nas associações de pós-graduação, entre outras. Na presente exposição, optou-se por centrar a análise em dois trajetos que compõe o núcleo central das redes que se estruturam em torno da Cadeira de Sociologia I da Universidade de São Paulo, particularmente 
pós-1954. Além disso, como indicado em outro lugar (BORDIGNON, 2010), de modo geral, essas redes e o conjunto de relações de sociabilidade constituídas nesse período se estendem para o período posterior. Ou seja, permanece um núcleo de agentes que passa a ocupar posições centrais na estruturação do espaço das ciências sociais no Brasil, particularmente pós-reforma universitária de 1968, e, ao mesmo tempo, a reivindicar uma legitimidade fundada em uma "tradição acadêmica". Os trajetos tomados para análise como casos exemplares são aqueles de Florestan Fernandes, que assume a Cadeira de Sociologia I da Universidade de São Paulo pós-1954, e Fernando Henrique Cardoso, seu assistente pós-1955.

\section{Duas trajetórias: Florestan Fernandes e Fernando Henri- que Cardoso ${ }^{3}$}

Nas relações entre origens sociais, modalidades e chances de ascensão "profissional" e concepções de ciências sociais estão imbricados, por um lado, o conjunto de estratégias e investimentos acionados para a realização das carreiras, por outro, uma adesão a certa definição de intelectual, aos usos do conhecimento científico e as filosofias sociais e políticas subjacentes.

No caso de Florestan Fernandes, o convívio com a família de sua madrinha, Hermínia Bresser de Lima, até os sete anos de idade, é muito importante. Isso porque, tal contato possibilitou o início de sua escolarização em uma instituição particular e, ao mesmo, a socialização relacionada a um padrão de vida diferenciado, com as respectivas aspirações sociais e, principalmente com a valorização da instrução, tornando possível àquilo que poucos da plebe conseguiam ter [...] através de experiências concretas. Isso foi importante porque o levou a valorizar a instrução, a querer ler e estudar, a procurar uma ponte para não se con- 
formar com aquela situação na qual se encontrava (FERNANDES apud SOARES, 1997, p. 23). Após a experiência de escolarização inicial, Florestan Fernandes abandona os estudos para ajudar no sustento da família, exercendo vários trabalhos manuais. A ruptura com a experiência inicial e a relação com um ambiente onde cada um conquistava o seu ponto com base no seu valor de luta (FERNANDES apud SOARES, 1997, p. 24-25), estrutura uma disposição para o conflito como modo de sobrevivência e de existência social. Nesse sentido, a necessidade de ganhar a vida proporciona-lhe um conhecimento prático dos usos possíveis de sua condição social e de seu passado como modo de acesso a determinadas oportunidades de ascensão "profissional" e social (FERNANDES, 1976, 1977, 1978).

A referência a um autodidatismo e certa disposição cultural, derivada da experiência de socialização inicial, mesclada com os usos de sua condição social e explicitação das respectivas barreiras que essa lhe impunha cria as possibilidades para o ingresso em vários espaços, dentre os quais, no Colégio Riachuelo, em 1937, por meio de uma concessão, através do professor Jair de Azevedo, para realizar os estudos com pagamento reduzido (FERNANDES, 1977, p. 147). O período de frequência ao Curso de Madureza e os exames para ingresso na Faculdade de Filosofia, Ciências e Letras (FFCL) da Universidade de São Paulo é descrito como o rompimento do círculo de ferro. 0 novo espaço de socialização configurado pela escolarização e pelo trabalho proporciona um tipo de circulação e de inserção social que o leva a melhores colocações no emprego e ao contato com as discussões sobre o socialismo e a sociedade brasileira, fato que incentivou a leitura mais sistemática das obras "clássicas" de formação socialista (Ibidem, p. 151). Com a "ajuda" da família de sua madrinha e através de vínculos específicos adquiridos na socialização do mundo do trabalho, Florestan Fernandes constitui uma base de sustentação que proporciona o investimento em um curso superior. No entanto, como era impossível realizar engenharia química devido à exigência de dedicação em tempo integral aos 
estudos (FERNANDES, 1991, p. 3-4), a aproximação com o movimento socialista e o engajamento nas lutas clandestinas contra o Estado Novo, levaram-no a uma inserção no ambiente de renovação cultural que pairava pela cidade de São Paulo, cujo centro irradiador era a FFCL e a secção de ciências sociais (FERNANDES, 1977, p. 155).

Logo após ingressar na Universidade de São Paulo começa a frequentar a empresa jornalística 0 Estado de São Paulo e, principalmente, a redação da Folha da Manhã, espaço no qual conheceu Hermínio Sacchetta, líder do movimento trotskista, ligado à IV Internacional (FERNANDES, 1991, p.5). Essas relações estabelecidas na redação d'0 Estado encaminharam sua militância no Partido Socialista Revolucionário (PSR) e no movimento trotskista, a partir de $1943^{4}$. Além disso, a empresa 0 Estado de São Paulo se constituía como uma espécie de "clube de cultura" em torno do qual circulavam importantes "figuras" (LIMONGI, 1989a, p. 112), dentre as quais, Antônio Candido de Melo e Souza e Fernando de Azevedo.

Desde o ingresso na universidade, Florestan Fernandes adota uma adaptação protetora, a qual significava aderir tacitamente às regras do jogo visando cultivar relações e suavizar as diferenças estruturais derivadas de sua origem social. Nessa estratégia de inserção, distingue dois planos de atuação: o da relação com os colegas; e o da relação com os professores. Com esses últimos, o contato foi propositalmente forçado, principalmente pela habilidade adquirida, desde a mais tenra idade como menino de rua. Tratava-se, portanto, de ter acesso aos professores fora dos contatos formais das salas de aula, o que foi conseguido através dos trabalhos de aproveitamento para as disciplinas. Dedicou-se com maior afinco a dois deles: um sobre a Evolução do Comércio Exterior no Brasil da Independência a 1940, passado pelo 
professor Paul Hugon; o outro sobre O Folclore em São Paulo, solicitado por Roger Bastide. Com o professor Hugon tudo evoluiu naturalmente e com muita rapidez, sendo que, ao expor as dificuldades pelas quais passara e sua experiência de vida, esse, inclusive, informou-lhe que arranjaria um emprego mais condizente com as aspirações que pleiteava. Igualmente, os contatos provocados com Roger Bastide renderam um convite para a discussão do trabalho sobre o folclore e o acesso a Sérgio Milliet e a contribuição com o jornal 0 Estado de São Paulo (FERNANDES, 1977, p.160-1).

Por intermédio dessas múltiplas inserções, passa a circular no interior de diversos espaços nos quais entrava em contato com membros da elite regional e nacional do período. Além disso, partir dos contatos iniciais com Roger Bastide cria-se um tipo de relação patronal por meio da qual Florestan passa a ter acesso a círculos variados de relações, o que amplia suas possibilidades de ascensão profissional. Dentre esses, pode-se destacar o ingresso na Escola Livre de Sociologia e Política, privilegiado por meio de contatos com Emílio Willems e Herbert Baldus, e o acesso a espaços de publicação e a prêmios. Os contatos e a exposição de suas aspirações e dificuldades derivadas da origem social estão na base das possibilidades de prosseguimento na carreira universitária, particularmente através da indicação para uma vaga de segundo assistente na Cadeira de Sociologia II, cujo catedrático era Fernando de Azevedo e o primeiro assistente, Antônio Candido (FERNANDES apud ABRUCIO et al. 2006, p.18).

As relações de solidariedade forjadas na convivência prolongada e no imperativo moral decorrente dos usos de sua condição social de origem estruturam as possibilidades de ascensão e de construção de uma carreira universitária fundada no capital de relações sociais proveniente da adesão às regras do jogo. Associado a isso, o fato de constituir-se por uma trajetória tangencial, notadamente em termos de origem social, favorece a dedicação aos estudos e reforça a crença no "mérito" e no "dom" como jus- 
tificativas de sua ascensão profissional, questões amplamente ostentadas, inclusive, por seus biógrafos autorizados (CERQUEIRA, 2004; SOARES, 1997; ARRUDA e GARCIA, 2003; SOUZA MARTINS, 1998). Nesse sentido, o amálgama entre as relações de patronagem e seu destaque como um aluno de grande produção cria as condições de legitimação dos postos alçados ao longo da carreira. Em 1942, inicia suas contribuições constantes nas revistas especializadas da época, cujos principais signatários eram Bastide, Baldus e Willems. Desse período até o final de seu doutorado, contam-se 11 artigos, 15 resenhas e 2 livros publicados, dentre os autores resenhados estavam Roger Bastide, Emilio Willems, Donald Pierson, Herbert Baldus, Egon Schaden e Sérgio Buarque de Holanda (JACKSON, 2004). Do mesmo modo, por vias de sua militância no movimento trotskista, em 1946, traduz e prefacia a Contribuição à crítica da Economia Política, de Marx, publicado pela Editora Flama, cujo "líder" era Hermínio Sacchetta.

A partir do ano de 1947, graças ao enorme prestígio de Fernando de Azevedo (CANDID0, 1996, p. 12), a hierarquia entre os assistentes fora destituída e esses passaram a ter regime integral, o que permite a Florestan deixar o trabalho de propagandista de uma empresa farmacêutica, levado concomitantemente a suas atividades na universidade, e dedicar-se unicamente a carreira "acadêmica" (FERNANDES, 1991, p. 4). Com uma participação constante nos processos de socialização universitária, Florestan passa a atuar, também, na Sociedade de Sociologia de São Paulo, fundada em $1934^{5}$, cujo presidente era Fernando de Azevedo. Essa associação representava o ponto de confluência e de organização das atividades dos sociólogos paulistas, tais como, o estabelecimento de convênios universitários, a representação

5 A primeira diretoria da Sociedade fora formada por: Fernando de Azevedo (Presidente); Júlio de Mesquita Filho (Vice-Presidente); Arbousse-Bastide (2o Vice-Presidente); Emilio Willems (Secretário); Cyro Berlinek (2ํㅗㄹ Secrário); Bruno Rudolfer (Tesoureiro). A partir de 1950, Sociedade de Sociologia de São Paulo passará a ser denominada Sociedade Brasileira de Sociologia (SBS). 
do grupo em entidades internacionais e a organização de atividades acadêmicas, dentre as quais os Congressos Brasileiros de Sociologia, iniciados em 1954.

O espaço de atuação organizado em torno dessa associação amplia a rede de relações e reforça uma inserção mais sistemática nos círculos universitários, bem como a participação no espaço de planejamento e definição das diretrizes da sociologia e de suas possibilidades de intervenção. 0 afastamento de Florestan do movimento trotskista é referido como um dilema moral: dedicar-se ao movimento socialista com o qual estava identificado e sacrificar a carreira intelectual, ou abandonar o movimento e intensificar sua atuação na universidade (FERNANDES, 1978, 1991). A resolução para esse "dilema" se dá através de sua atuação como sociólogo a partir das experiências da militância política. Mais especificamente, passa a reivindicar a não separação entre o mundo da militância e o mundo universitário, tratando-se, portanto, de inserir a atuação universitária no papel da militância socialista-marxista.

O sociólogo isolou-se demais no passado, em detrimento de sua liberdade intelectual, do aproveitamento dos resultados das investigações sociológicas pela sociedade e de sua própria influencia constitutiva sobre os acontecimentos. Cumpre-nos tentar modificar esta situação e, em especial, procurar um novo enlace com o movimento socialista, o único que poderá, a médio prazo, tirar o sociólogo de seu confinamento intelectual e aproveitar, praticamente, as contribuições de uma sociologia verdadeiramente crítica e militante (FERNANDES, 1977, p. 138-9).

Essa concepção do fazer sociológico, como uma espécie de "ir ao povo", se expressa na organização e realização do projeto sobre relações raciais no Brasil contratado pela Organização das Nações Unidas para a Educação, a Ciência e a Cultura (UNESCO), a 
partir de 1951. Vinculado ao conjunto de redes de pesquisa que se organizam a partir dos anos de 1950, uma das partes desse projeto é coordenada por Roger Bastide e Florestan Fernandes (FERNANDES, 2003, p.142). Nessa época, Fernando Henrique Cardoso atuava como auxiliar voluntário de Bastide, o que contribui para o estabelecimento de relações mais diretas e sistemáticas entre ambos.

Ao contrário de Florestan Fernandes, Fernando Henrique Cardoso já dispunha, desde o início, de um capital de relações sociais ligado ao grupo familiar, particularmente às posições de exercício do poder político e militar. Além disso, a convivência pessoal com os "agentes" do "campo do poder" no Brasil configura um conjunto de entradas em espaços distintos de poder que extrapolam o âmbito da universidade (CARDOSO, 2006, p. 50). Nascido no Rio de Janeiro, se muda para São Paulo em 1940, por conta da transferência de seu pai para a Segunda Região Militar. No período em que cursava o secundário no Colégio São Paulo, engaja-se na política estudantil e nas campanhas pela anistia dos presos e perseguidos políticos do Estado Novo. Atuando juntamente com seu pai, envolve-se nas campanhas nacionalistas e aproxima-se do Partido Comunista Brasileiro (PCB) de São Paulo e da Revista Brasiliense, capitaneada por Caio Prado Junior e Elias Chaves Neto. Através dessas relações, passa a integrar o corpo editorial da Revista Fundamentos, lançada pela Brasiliense em 1948.

Ingressando na Faculdade de Filosofia, Ciências e Letras em 1949 , após ter sido reprovado no exame para o ingresso na Faculdade de Direito do Largo São Francisco (GARCIA Jr., 2004, p. 289), em 1950, passa a colaborar como auxiliar voluntário da Cadeira de Sociologia I, sob o comando de Roger Bastide. Ao mesmo tempo, envolvido na campanha pela nacionalização da exploração do petróleo, participa da formação de grupos de apoio ao movimento e insere-se no escopo de atuação do Centro de Estudos de Defesa do Petróleo e da Economia Nacional 
(CEDPEN), do qual seu pai fora fundador e seu tio presidente, e contribui na criação da Liga de Emancipação Nacional (LEN), fundada em 1953, da qual seu pai será o procurador-geral.

Paralelamente ao envolvimento político nas campanhas nacionalistas ao lado de membros de sua família, Fernando Henrique passa a trabalhar na pesquisa desenvolvida por Roger Bastide e Florestan Fernandes sobre relações raciais no Brasil. No período entre 1951 e 1952 aproxima-se de forma mais sistemática de Florestan, o qual o indica para trabalhar na Faculdade de Economia e Administração, arranjando a vaga através de contato com Mario Wagner Vieira da Cunha, catedrático, diretor e membro fundador do Instituto de Administração (IA) da Universidade de São Paulo. No IA, trabalha com Lucila Hermann, assistente de Wagner, e Maria Sylvia de Carvalho Franco, em uma pesquisa no Palácio das Indústrias de São Paulo.

A inserção de Fernando Henrique no IA, a aproximação com Mario Wagner e sua amizade de Maurício Segall, facilitam sua indicação, em 1952, para trabalhar com Alice Cannabrava, como assistente de Cátedra. Como não havia concluído a graduação, e não poderia assumir o cargo por falta de titulação, precisou da expedição de uma portaria de autorização do reitor para poder ser nomeado assistente na Faculdade de Economia. Feito isso, leciona História Econômica da Europa, acompanha os cursos de Dorival Teixeira Vieira e aproxima-se de Delfim Netto. Por desentendimentos com a professora catedrática e pelo padrão de trabalho empregado por essa (CARDOSO, 2008, p. 7), Fernando Henrique sai da Faculdade de Economia e vai trabalhar na Secretaria do Trabalho de São Paulo, juntamente com Ruth Corrêa Leite e Eduardo Tess, que, liderados por Celeste Andrade, realizam uma pesquisa sobre desemprego no Brasil (CARDOSO apud ABRUCIO et al. 2006, p.70-71).

O projeto sobre relações raciais representou uma das primeiras oportunidades de intervenção direta no mundo social. Segun- 
do Florestan, houve uma inovação na pesquisa através da preocupação em dar voz aos de baixo e de romper com o silêncio do preconceito. A estrutura de pesquisa dinamizava-se com a integração do negro na universidade, o que consistia em dar uma consciência política e organização ao movimento (FERNANDES, 1978, p. 91-102). Florestan e Bastide engajaram-se nesse projeto (MAIO, 1999), o que proporcionou um marco na trajetória de Florestan, uma vez que esse assumiu simbolicamente a consagração que o destacava como o sociólogo mais completo de sua geração (CANDIDO, 1996, p. 13-14).

A modalidade de organização e realização da pesquisa evidencia, também, a definição do fazer sociológico que vai orientar a atuação do grupo que será encabeçado por Florestan Fernandes, a partir de 1954. Tratava-se de ultrapassar uma sociologia profissional ressentida e confinada na universidade, de modo a por os conhecimentos definidos a partir da pesquisa científica a serviço da comunidade e da transformação social e política (FERNANDES, 1977). Essa concepção do fazer sociológico e dos usos do conhecimento científico como modo de transformação social coaduna-se com a própria concepção de universidade que está na base dos projetos levados a cabo em São Paulo. Ou seja, tratava-se de criar uma elite numerosa e organizada, instruída sob métodos científicos [...] capaz de compreender antes de agir [...] que inspire confiança ao povo e lhe ensine passos firmes e seguros (KANTOR, MACIEL e SIMOES, 2009, p. 236).

Em 1952, Florestan Fernandes assume como assistente de Roger Bastide na Cadeira de Sociologia I e arranja com esse a inserção de Fernando Henrique Cardoso no quadro de auxiliares da cátedra. Assim que assume a Cátedra de Sociologia I como professor contratado, em 1954, Florestan nomeia Fernando Henrique para assistente, o que causou muito ciúme no grupo. Ao que tudo indica, o candidato direto para a nomeação era Renato Jardim Moreira, que vinha trabalhando com Florestan desde a pesqui- 
sa da UNESCO, mas Cardoso foi nomeado "primeiro" assistente ${ }^{6}$. Como destaca, Florestan fez uma violência para me proteger e me nomeou primeiro assistente na frente de todos os demais (CARDOSO apud SOARES, 1997, p. 63), criando aquele clima. Mas o Florestan tinha isso, ele gostava da competição (CARDOSO apud ABRUCIO et al. 2006, p. 72-73).

Muito antes de se tratar de um incentivo à competição ou o reconhecimento de determinadas competências ligadas à produção acadêmica ${ }^{7}$, o que estava em pauta era a constituição do grupo que vai gravitar em torno da Cadeira de Sociologia I, sob o comando de Florestan, o qual se organiza através de uma lógica de "autoproteção", de formação de uma "escuderia" e da definição de uma lógica de ação com perspectiva mobilização coletiva. 0 objetivo era formar um grupo estruturado em torno de uma posição definida e que, a partir de uma lógica interna, controla a expansão e o recrutamento segundo critérios pré-definidos de atuação (FERNANDES, 1977, p. 185). Ao mesmo tempo, o fortalecimento e consolidação do próprio grupo estão vinculados ao acesso a recursos e a capacidade de mobilização desses de que dispõem seus membros. Quando nomeado assistente, Fernando Henrique Cardoso dispunha de um conjunto de entradas em diversas esferas de poder. No início de 1954, por conta da Convenção da Emancipação Nacional, realizada no Rio de Janeiro, seu pai torna-se presidente da LEN e é um dos indicados pelos comunistas para concorrer ao cargo de Deputado Federal pela sigla do Partido Trabalhista Brasileiro (PTB) de São Paulo. Nesse mesmo ano, Fernando Henrique, em uma aliança com a Faculdade de Economia e a de Medicina, foi eleito representante dos ex-alunos no Conselho Universitário, tendo como suplente Delfim Netto.

6 Hierarquia simbólica que representava o substituto direto do Catedrático, caso esse se ausentasse.

7 Fernando Henrique Cardoso não possuía produção significativa até o momento, contando apenas uma resenha publicada na Revista Fundamentos. 
A mobilização de alianças internas ao PCB permite que conte com o apoio de uma dissidência da Faculdade de Direito, juntamente com isso, a circulação interna na USP e o capital de relações sociais ligado ao grupo familiar criam as possibilidades para que se torne o mais jovem membro do Conselho Universitário da USP e com uma influência muito grande no mesmo (CARDOSO, 2008, p. 11).

[...], fui para o Conselho Universitário da USP [...]. Então fui para a reitoria, onde quem mandava naquela época eram os professores Camargo, da política, Honório Monteiro que tinha sido ministro do trabalho do Dutra, e Zeferino Vaz. [...] meu pai era deputado pelo PTB, o presidente do Banco Central era meu tio, o prefeito do Rio e o Ministro da Guerra eram meus primos [...]. É, eles descobriram que eu tinha "poder na República". E me levaram ao Rio porque tinham que liberar uma verba. (CARDOSO apud ABRUCIO et al. 2006, p. 74).

Florestan Fernandes e Fernando Henrique Cardoso mobilizavam um conjunto de recursos institucionais e sociais que, em ampla medida, transcendiam os limites da Cadeira de Sociologia I e, inclusive, da universidade. Do mesmo modo, a estrutura e o conjunto da rede de relações que mobilizam é amplamente diferente, a começar pelo capital de relações sociais ligado ao grupo familiar e, consequentemente, as modalidades de atuação e alianças forjadas ao longo de seus trajetos, as quais estruturam a capacidade de manter ou reconverter seus recursos em espaços sociais distintos. Particularmente a partir de seu ingresso no Conselho Universitário, Fernando Henrique envolve-se com o movimento de reforma da universidade, do qual se torna um dos líderes. Participando juntamente com Villanova Artigas e Juarez Brandão Lopes, mobilizam-se no processo de renovação política, administrativa e arquitetônica da USP. Ao lado de Alberto Carvalho da Silva, integrante da Faculdade de Medicina, atua 
nas reivindicações para a regulamentação da carreira de assistente, de modo que essa não ficasse mais a mercê dos mandos e desmandos do professor catedrático (CARDOSO, 2006, p. 28). Ao mesmo tempo, vincula-se as articulações e a organização de apoios para a candidatura de Antônio Barros de Ulhôa Cintra a reitor da universidade e para a criação da Fundação de Amparo a Pesquisa do Estado de São Paulo (FAPESP).

A sobreposição e acionamento de redes de atuação em diversos espaços sociais são estruturantes na constituição da carreira de Fernando Henrique e em suas possibilidades de acesso a recursos variados. 0 envolvimento constante na política universitária e a ligação familiar com a política nacional e estadual legitimam sua posição central em redes de reciprocidade e inter-reconhecimento diversas. Entre essas alianças, estão aquelas que vão formar o núcleo duro do grupo de estudos sobre Marx $^{8}$ (CARDOSO apud ABRUCIO et al. 2006, p. 75), e as que vão possibilitar a criação do Centro de Sociologia Industrial e do Trabalho (CESIT).

Estruturado como início da ruptura com a tutela exercida por Florestan Fernandes, o Seminário d'O Capital representava $a$ emancipação intelectual e a afirmação de uma nova geração que estava interessada em ocupar o seu espaço, em brilhar (CARDOSO apud SOARES, 1997, p. 62). Como modalidade de ruptura, $a$ proposta de um grupo que não teria Florestan como líder, e sim Fernando Henrique Cardoso, representou a iniciativa mais ambiciosa do período e o início de uma relação de forças que vai cindir o grupo formado em torno da Cadeira de Sociologia I (COHN apud ABRUCIO et al. 2006, p. 120-1). O processo de criação do CESIT, logo no começo da década de 60, se efetiva pelo acesso de Fernando Henrique à Confederação Nacional das Indústrias 
$(\mathrm{CNI})^{9}$. Além disso, sua influencia através do Conselho Universitário e a influência de Florestan Fernandes como principal expoente da sociologia no Brasil contribuíram para viabilizar o centro (FERNANDES apud ABRUCIO et al. 2006, p. 21-23). Devido a contatos com Georges Friedmann ${ }^{10}$ e seu assistente Alain Touraine, Fernando Henrique Cardoso é indicado como diretor do CESIT e, como se tratava de um órgão de pesquisa vinculado a Cadeira de Sociologia I, Florestan Fernandes fica com o cargo de presidente. Florestan e Fernando Henrique formavam "nódulos" de poder que transcendiam a estrutura de cátedra em termos de mobilização de recursos, o que significou a afirmação do grupo e sua estruturação para além da universidade. No entanto, a qualidade e quantidade desses vínculos e os recursos a que davam acesso eram muito diferentes. No caso de Florestan Fernandes, todos os seus recursos se constituíram a partir da universidade e por meio da atuação junto a movimentos sociais, ao contrário, o acesso de Fernando Henrique a instancias de poder é independente de seu ingresso na USP, ao passo que, inclusive, os recursos vinculados à herança são, de diversos modos, constantemente reconvertidos em relações que permitem o acesso à universidade e a sua administração.

Além disso, Fernando Henrique passa a estabelecer contatos, a partir do final dos anos 50, com o Centro Latino-Americano de Pesquisas em Ciências Sociais (CLAPCS) ${ }^{11}$, vinculado a UNESCO e lugar de intensa atividade e de discussão sobre a temática do

9 Arranjei recursos com o Fernando Gasparian, que era meu amigo e cuja mulher, Dalva, tinha sido colega da Ruth no colégio em São Paulo. Fernando foi nomeado pelo Jango como interventor na Confederação Nacional das Indústrias, a CNI. Assim, arranjei uma verba para fazer a pesquisa [...]. Eu tinha muito cuidado para o Florestan não imaginar que eu quisesse ameaçar o poder dele (CARDOSO apud ABRUCIO et al. 2006, p. 74).

10 Como eu tinha automóvel e falava francês, andei com ele [Georges Friedmann] por São Paulo (CARDOSO, 2008, p. 9).

11 Participavam de atividades no CLAPCS, dirigido por Luiz de Aguiar Costa Pinto, uma série de intelectuais, entre eles estavam, Gino Germani, Rodolfo Stavenhagen, Torquato Di Tella, Jorge Graciarena. 
desenvolvimento na América Latina. Após concluir sua tese de doutorado, em 1961, vai para Buenos Aires, onde reforça os contatos estabelecidos no CLAPCS. De volta da Argentina, no ano seguinte vai para a França, a convite de Touraine. 0 monopólio de uma posição social de "elite tradicional" no Brasil e o acúmulo de um capital cosmopolita viabiliza sua circulação internacional e a aquisição de recursos variados associados à inserção nos círculos intelectuais internacionais (DEZALAY, 2004). Por meio da ostentação de títulos e de relações pessoais com intelectuais reconhecidos (CARDOSO apud ABRUCIO et al. 2006, p. 84-85), Fernando Henrique constitui-se, também, como "mediador cultural" em um país política e culturalmente dependente como o Brasil. Do mesmo modo, as redes de circulação e a posição social nacional dinamizam uma gama de recursos possíveis e as possibilidades de legitimação dessa circulação como recurso no espaço "acadêmico".

Ao contrário, durante o mesmo período Florestan Fernandes, ancorado na universidade, reforça seus laços com os de baixo e atua diretamente como mediador entre a produção cultural e a luta política. Em 1962, como presidente da Sociedade Brasileira de Sociologia, profere o discurso de abertura do II Congresso Brasileiro de Sociologia, realizado em Belo Horizonte. Engajado no movimento em defesa da escola pública, reforça o papel "inerente" a atuação do sociólogo como agente de inovação institucional e, ao mesmo tempo, como produtor de uma modalidade do saber científico (FERNANDES, 2003, p. 52). 0 engajamento de Florestan no movimento de defesa da escola pública se inicia em 1959, e como destaca, fora "empurrado" para isso por diversas razões, entre as quais, seus vínculos com Fernando de Azevedo, Anísio Teixeira e Júlio de Mesquita Filho, a constante inserção nas pesquisas educacionais e a atuação junto aos movimentos sociais. A partir deste movimento e do subseqüente contexto de "injunção social" que passa a se configurar na década de 1960, a visibilidade de Florestan se consolida através da mobilização de um capital de notoriedade derivado da ocupação da Cátedra de Sociologia e 
da publicização das lutas nas quais se envolve em nome da conscientização dos de baixo (FERNANDES, 2003a, p 146). Isso ocorre, particularmente, porque o movimento tomou grandes proporções, principalmente através de Júlio de Mesquita Filho e Paulo Duarte que garantiram larga cobertura publicitária no jornal 0 Estado de São Paulo (FERNANDES, 1978, p. 50-69).

Nesse processo de inserção e militância, Florestan amplia sua circulação nacional, através da rede de pesquisas educacionais, e passa a transitar pelos estados brasileiros e proferir palestras em Recife, Salvador, Belo Horizonte, Rio de Janeiro e Porto Alegre. Como catedrático da FFCL, tem acesso a alta burocracia universitária e é membro permanente da Congregação. Do mesmo modo, suas relações com Júlio de Mesquita Filho, Antônio Candido de Mello e Souza, Mario Wagner Vieira da Cunha, Fernando de Azevedo, Paulo Duarte, Caio Prado Junior, Anísio Teixeira, entre outros, permitem-lhe uma circulação intra-elites e a participação em círculos de reciprocidade cuja posição social de seus interlocutores estava diretamente vinculada ao campo do poder. Por outro lado, o engajamento em diversos movimentos sociais, além do uso do passado como modo de legitimação das tomadas de posição a favor dos de baixo, permitem-lhe gozar de grande visibilidade entre os estudantes e líderes desses movimentos.

No entanto, a circulação intra-elites, notadamente intra grupo d'0 Estado passa a se romper com a adesão de Florestan as reformas de base, com a radicalização de suas tomadas de posições, e com a intensificação da militância política. Do mesmo modo, a atuação como um franco atirador em plena atividade cria conflitos internos à universidade e à Congregação da FFCL. Florestan exerce uma militância intensa, voltado à conscientização das massas e à condução da revolução, passando a definir os padrões de atuação intelectual segundo os princípios de adesão e responsabilidade social frente a determinadas causas, visto que, o sociólogo é um cidadão em condição especial, uma espécie de guarda avançada da consciência nacional (FERNANDES, 
1976, p. 122). Essas concepções de ciências sociais como modos de instrumentalização de tomadas de posição políticas são compartilhadas por Fernando Henrique Cardoso, embora, para esse essas tivessem muito mais um papel auxiliar na "administração" e no "governo", funcionando como uma forma de adequação das instituições à realidade nacional (CARDOSO, 1958, p. 76-77).

Com a instauração do regime militar em 1964 e a instalação do Inquérito Policial Militar (IPM) na USP, tem início um período declarado de radicalização interna à universidade e de caça as bruxas. Segundo Florestan Fernandes (1984), a ditadura militar toma conotações de terrorismo cultural ao ponto de se transformar em arma de ascensão e de resolução de desafetos internamente ao ambiente universitário. Em outubro de 1964 as investigações divulgam a lista dos "comunistas", a qual inclui os nomes de Florestan Fernandes, Fernando Henrique Cardoso, Caio Prado Junior, Mario Wagner Vieira da Cunha, Paul Israel Singer, e outros "convidados" a depor ao "regime" interno da USP (ADUSP, 2004). 0 nome de Florestan Fernandes é incluído entre os primeiros professores a depor. Embora Júlio de Mesquita Filho tenha se oferecido para pedir ao general Orlando Geisel que retirasse seu nome da lista (CERQUEIRA, 2004, p. 91-100), Florestan não aceita e vai prestar depoimento com a intenção de "utilizar politicamente o evento" (FERNANDES, 1984, p. 101). 0 fato emblemático da entrega de uma carta ${ }^{12}$ ao tenente-coronel responsável pela ação militar na universidade é resgatado por todas as biografias e materiais de cunho hagiográfico de Florestan Fernandes. Além disso, o fato do posicionamento frente à omissão da Universidade que aceitou com passividade as imposições da ditadura militar evidencia uma ruptura interna na Faculdade de Filosofia, Ciências e Letras e o contraste entre as posições dos professores, diretores de faculdade e alunos. Mais especificamente, Florestan defendia um posicionamento institucional da universidade frente ao terrorismo cultural e aos re- 
cursos de intimidação utilizados pela polícia política, mas, como destaca, não vingou a atitude que eu defendia - 'por nós não passarão!! Após a apresentação da carta ao tenente-coronel, Florestan é preso. No entanto, um esquema estava armado para a difusão do material e para a comunicação da imprensa. Segundo ele, a eficiência dos estudantes foi tamanha que ao chegarmos à sede da Segunda Região Militar já estavam lá os jornalistas a minha procura (Ibidem).

Ao imprimir uma diretriz de ruptura com os interesses que orientavam a atuação das elites, Florestan perde parte da base de apoio que estruturou as condições de possibilidade para a construção de sua carreira na universidade. Nesse período de engajamento constante e de afirmação de um perfil de intelectual identificado com os problemas dos de baixo, Florestan inicia a preparação do livro A Revolução Burguesa no Brasil como uma resposta à situação política. Os escritos iniciais produzidos durante sua estadia em Columbia passam a circular entre os colaboradores da Cadeira de Sociologia I e dividem o grupo, provocando reações e desentendimentos, fato que evidencia a penetração do terrorismo e do consequente sentimento de autoproteção individual no interior de um grupo formado segundo a lógica de uma organização de luta coletiva ${ }^{13}$. De acordo com Florestan Fernandes, a reação ao livro fora mais ferrenha, principalmente porque o argumento central gira em torno do bloqueio da transformação a partir de dentro. A análise de uma reação sociopática à mudança representava, antes de tudo, uma crítica à estrutura interna da universidade e, especialmente, do grupo encampado na Cadeira de Sociologia I, ou seja, no interior da estrutura tivemos nossos Fariseus, os nossos Pilatos e os nossos Judas (FERNANDES, 1977, p. 215).

13 Companheiros que se desgarraram, que não entenderam sua época e seus papéis intelectuais, que empunharam as armas erradas e acabaram ignorando a pugna certa, o terreno correto, o inimigo comum inevitável (FERNANDES, 1977, p. 215). 
Quando o nome de Fernando Henrique Cardoso sai na lista do IPM da USP, esse já se encontrava em exílio voluntário. Aceitando um convite para lecionar na Argentina, permaneceu em Buenos Aires aproximadamente um mês. Posteriormente, foi convidado para trabalhar na Comissão Econômica para a América Latina e o Caribe (CEPAL) sediada no Chile ${ }^{14}$, país que se configura como grande centro aglutinador de intelectuais do período, tornando-se um espaço de sociabilidade e confluência de redes de movimentação internacional, alargadas no período do regime ditatorial latino-americano. Como destaca Fernando Henrique, no Chile tive contato com intelectuais de toda a América Latina (CARDOSO, 2008, p. 15). Em 1965, José Medina Echevarría ${ }^{15}$ o indica para o cargo de diretor-adjunto da divisão de estudos sociais do Instituto Latino-Americano e do Caribe de Planejamento Econômico e Social (ILPES). No comando do instituto, Fernando Henrique passa a estar protegido dentro da burocracia da ONU. Em uma posição institucionalmente privilegiada e legitimada pelo capital de relações sociais que a sustenta, intensifica sua atuação intelectual, participando de conferências e palestras nos Estados Unidos e na França, fato que lhe permite conhecer a ONU por dentro (CARDOSO apud ABRUCIO et al. 2006, p. 82-83). No ano de 1967, Alain Touraine convida-o para dar aulas na Université Paris-X, reforçando um conjunto de redes prévias e uma posição de mediação entre o "campo" intelectual nacional e o internacional. Durante o período na França, produz o trabalho que servirá para o concurso da Cátedra de Ciência Política na FFCL que estava vaga, já que o antigo titular e amigo de Fernando Henrique, Lourival Gomes Machado ${ }^{16}$, havia faleci-

14 Entre as relações que favorecem o deslocamento de Fernando Henrique para a CEPAL, pode-se destacar a amizade com José Medina Echevarría, Raul Prebisch e Celso Furtado.

15 Echavarría estivera em São Paulo em 1959 organizando um seminário da UNESCO sobre urbanização na América Latina e entra em contato com a secção de Sociologia da FFCL e com Juarez Brandão Lopes, da Faculdade de Economia e Administração.

16 Em uma discussão com Florestan Fernandes no período anterior a defesa de sua tese de doutorado, Fernando Henrique Cardoso ameaça mudar de orientador e defender sua tese com Lourival Gomes Machado, com quem se dava bem (CARDOSO apud ABRUCIO et al. 2006, p. 77). 
do. Já que quando é convocado para depor no Inquérito Policial Militar da USP, Fernando Henrique Cardoso não estava no Brasil, não compareceu e teve sua prisão decretada pelo Tribunal Militar. Informado de que não poderia voltar ao Brasil, pois seria preso, Fernando Henrique consegue revogar a ordem de prisão por meio de um habeas corpus concedido pelo Supremo Tribunal Militar (SPM) e conquistado por meio da intervenção de um amigo da família, o general Peri Bevillacqua.

Com a aprovação no concurso para professor catedrático, Fernando Henrique Cardoso passa a compor a Congregação da FFCL. No contexto do regime militar e de radicalização do conflito político, Florestan Fernandes toma o centro dos debates e passa a figurar como uma das principais lideranças intelectuais do período, estando à frente de diversas lutas e manifestações. Em 1968, a reunião da Congregação evidencia as disputas internas à universidade e, particularmente, marca a ruptura entre Fernando Henrique Cardoso e Florestan Fernandes. Esse último reivindica o posicionamento institucional e público da Faculdade de Filosofia, Ciências e Letras frente ao sentido da evolução política da ditadura [...], e a maquinação contra a universidade e sua função crítica. Dentre as resistências ao seu pedido de manifestação pública e do envolvimento da Faculdade na luta contra a ditadura, está a contraproposta apresentada por Fernando Henrique Cardoso que sugere, ao contrário, que o posicionamento dos professores seja registrado em ata e, por isso, conste burocraticamente, como nota de repúdio. Ao ser vencido pela proposta de Fernando Henrique Cardoso, Florestan Fernandes, ficou ressentido e intimamente furioso, pois não aceitava a solidariedade passiva que demonstrava que a FFCL não estava madura para um outro tipo de resposta a uma agressão externa fulminante e, ao mesmo tempo, esperava solidariedade de seu antigo orientando e assistente (FERNANDES, 1984, p. 105-6). 
Quadro 1 - Origens sociais, Carreira e Prêmios

\begin{tabular}{|c|c|c|}
\hline $\begin{array}{l}\text { Nome, origem social, } \\
\text { data de nascimento e } \\
\text { escolarização }\end{array}$ & Carreira & Prêmios e Títulos \\
\hline \multicolumn{3}{|c|}{$\begin{array}{l}\text { Florestan Fernandes (1920) } \\
\text { Pai: Desconhecido | Mãe: Empregada c }\end{array}$} \\
\hline $\begin{array}{l}\text { - Curso primário incom- } \\
\text { pleto. } \\
\text { - Curso de Madureza. } \\
\text { - Graduação em Ciências } \\
\text { Sociais (1944) FFCL/ } \\
\text { USP } \\
\text { - Mestrado em Antropo- } \\
\text { logia (1947) ELSP/SP } \\
\text { - Doutorado em Sociolo- } \\
\text { gia (1951) FFCL/USP } \\
\text { - Livre-docência (1953) } \\
\text { FFCL/USP }\end{array}$ & $\begin{array}{l}\text { - Professor Assistente da Cadei- } \\
\text { ra de Sociologia II (1945/1952) } \\
\text { - Professor Assistente da Cadei- } \\
\text { ra de Sociologia I (1952/1953) } \\
\text { - Professor contratado da Cadei- } \\
\text { ra de Sociologia I (1954/1964) } \\
\text { - Professor Catedrático da Ca- } \\
\text { deira de Sociologia I - FFCL/ } \\
\text { USP (1965/1969) } \\
\text { - Presidente do CESIT (1961/ } \\
\text { 1968) } \\
-\quad \text { Presidente da SBS }(1960 / \\
1962)\end{array}$ & $\begin{array}{l}\text { - Prêmio Temas Brasileiros } \\
\text { FFCL/USP (1944) } \\
\text { - Prêmio Fábio Prado } \\
\text { (1948) } \\
\text { - Medalha Silvio Romero - } \\
\text { Prefeitura do Rio de Janeiro } \\
(1958) \\
\text { - Título de Cidadão Emérito } \\
\text { - Câmara Municipal de São } \\
\text { Paulo (1961) } \\
\text { - Prêmio Jabuti de Ciências } \\
\text { Sociais (1963) } \\
\text { - Prêmio Sociedade Brasil- } \\
\text { Israel (1966) } \\
\text { - Prêmio The Anisfield-Wolf } \\
\text { Award in Race Relations } \\
\text { - Cleveland Foundation } \\
\text { (1969) }\end{array}$ \\
\hline \multicolumn{3}{|c|}{$\begin{array}{l}\text { Fernando Henrique Cardoso (1931) } \\
\text { Pai: Militar, Advogado e Político. | Mãe: Sem informação }\end{array}$} \\
\hline $\begin{array}{l}\text { - Curso primário e secun- } \\
\text { dário regulares. } \\
\text { - Graduação em Ciências } \\
\text { Sociais (1952) FFCL/ } \\
\text { USP } \\
\text { - Mestrado em Sociologia } \\
\text { (1953) FFCL/USP } \\
\text { - Doutorado em Sociolo- } \\
\text { gia (1961) FFCL/USP } \\
\text { - Pós-Graduação no La- } \\
\text { boratoire de Sociolo- } \\
\text { gie Industrielle/Paris } \\
\text { (1962-1963) sob a dire- } \\
\text { ção de Alain Touraine. } \\
\text { - Livre-docência (1963) } \\
\text { FFCL/USP. }\end{array}$ & \begin{tabular}{|l} 
- Professor Assistente IA/USP \\
(1952) \\
- Auxiliar da Cadeira de Sociolo- \\
gia I (1953) \\
- Professor assistente da Cadei- \\
ra de Sociologia I (1954/1964) \\
- Professor - Universidade de \\
Paris X - Nanterre (1967/1968) \\
- Professor Catedrático da ca- \\
deira de Ciência Política - FFCL/ \\
USP (1968/1969) \\
- Representante dos Ex-Alunos \\
no Conselho Universitário da \\
USP (1954/1960) \\
- Diretor do CESIT (1961/1964) \\
- Diretor-Adjunto do ILPES/Ce- \\
pal (1965/1966)
\end{tabular} & \\
\hline
\end{tabular}

Fonte: DHBB/CPDOC-FGV; CERQUEIRA, 2004; SOARES, 1997; SACCHETTA, 1995. 
Na primeira lista de aposentadorias compulsórias decorrentes do AI-5, em abril de 1969, está o nome de Florestan Fernandes. Tendo chegado ao topo da carreira universitária em 1954, ao assumir a Cadeira de Sociologia I, e conquistado o reconhecimento por sua atuação política e seu controle de recursos institucionais, a cassação desmonta sua base de legitimação e corta significativamente suas possibilidades de intervenção a partir de um posto institucionalmente reconhecido. Além disso, a perda súbita de parte substancial da renda, a necessidade de acumular alguns trabalhos remunerados de natureza intelectual e a premência de sair do país, associadas à negativa de trabalhar no Centro Brasileiro de Análise e Planejamento (CEBRAP), marcam significativamente os deslocamentos posteriores de seu trajeto (SOARES, 1997, p. 76-79). Todos os recursos utilizados por Florestan na formação do um grupo que gravitava em torno da Cadeira de Sociologia I estavam baseados em seu controle institucional das nomeações e destituições, de modo que, sua aposentadoria compulsória representou a perda do acesso aos recursos e sua possibilidade de redistribuição desses de modo a retribuir as dedicações específicas dos membros do grupo do qual é o líder. A significância da posição ocupada na estrutura de capitais de que dispõe Florestan é muito significativa, de modo que, ao ser destituído do cargo, vê-se desarvorado e numa crise que é psicológica é moral e é política ocasionada pela perda de um ponto de referência e de identidade determinante para a sua sobrevivência e seu trabalho (FERNANDES, 1978, p. 70).

No caso de Fernando Henrique Cardoso, após perder o cargo de professor catedrático recentemente conquistado, reconverte um conjunto de alianças antigas, forjadas e cimentadas em ocasiões anteriores, tais como o movimento de reforma da universidade, ou na participação do grupo d'O Capital, ou na luta pela criação da FAPESP (LOPES apud ABRUCIO et al. 2006, p. 105) na criação do CEBRAP. A viabilidade desse centro, como órgão aglutinador da intelectualidade brasileira no período ditatorial, está fundamentada no conjunto de redes e contatos externos que consegue 
mobilizar através de seus membros, particularmente, os recursos financeiros da Fundação Ford e do Banco Interamericano de Desenvolvimento (BID). Principal articulador dos apoios, Fernando Henrique Cardoso dispunha de conhecimento do mundo das fundações, adquirido a partir de sua participação na CEPAL e na ONU (CARDOSO, 2008, p. 19), e possuía contatos com Candido Mendes, que ofereceu sua fundação para viabilizar o acesso aos recursos necessários à construção do centro de pesquisas (SORJ, 2001, p. 31-32).

De modo geral, polarização entre uma postura de ruptura radical ou de coalizão (PÉCAUT, 1990, p. 291), princípios de atuação e de visão que estruturam os confrontos entre Florestan Fernandes e Fernando Henrique, relacionam-se as próprias condições de possibilidade de manutenção e reprodução de suas posições sociais. Para o caso de Florestan, a condição de professor catedrático definia e estruturava sua posição social, visto que representava sua rede de sustentação, material e simbólica, a frente de um grupo. 0 significado "cargo" para a estrutura de capitais de Florestan Fernandes leva-o a engajar-se em uma luta contínua para sua manutenção. No entanto, ao contrário das estratégias utilizadas para a constituição de sua carreira e para a conquista do "cargo", particularmente baseadas no investimento em relações de reciprocidade e no esforço para "jogar o jogo", a partir da modificação da condição de aspirante à cátedra para professor catedrático, modificam-se os modos de atuação. Florestan Fernandes passa, então, a um investimento contínuo na atuação em nome dos de baixo na utilização da mobilização coletiva como instrumento de luta.

Ao contrário, Fernando Henrique Cardoso dispõe de uma ampla gama de recursos de sustentação, estruturados para além de quaisquer posições que tenha ocupado na estrutura universitária. Mesclando redes diversas derivadas do grupo familiar, da atuação política e de uma condição socialmente dominante, a forte inserção em grupos nacionais e internacionais e a varie- 
dade de seus investimentos permitem-lhe constituir uma carreira intelectual na qual a ocupação de uma posição na estrutura universitária seria apenas mais um recurso entre tantos outros ostentados e passíveis de mobilização.

\section{Considerações finais}

A preocupação inicial presente na exposição de uma série de indicações derivadas de uma pesquisa realizada anteriormente, estava centrada na exploração das relações entre origens sociais, modalidades e chances de ascensão profissional e as concepções de ciências sociais subjacentes. Com o objetivo de discutir alguns dos efeitos da décalage entre posição social de origem e posição atual ou potencial dos trajetos, foram expostos dois casos contrastantes de constituição de carreiras universitárias em um período pré-1968 no Brasil.

Como foi possível notar a partir do contraste entre as trajetórias de Florestan Fernandes e Fernando Henrique Cardoso, a origem social tem efeitos significativos nas modalidades de investimentos, nos esquemas de ação aplicados em diferentes situações e nos significados que determinadas posições tem na estrutura de capitais que compõe os trajetos dos agentes em pauta. No caso de Florestan Fernandes, com uma origem social extremamente baixa, as possibilidades de acesso à escolarização elementar e a universidade estavam associadas à disponibilidade de determinadas redes de proteção derivadas de relações assimétricas, ou seja, da "ajuda" dispensada por aqueles contatos que se encontravam em melhores condições sociais. Isso está igualmente presente na estruturação da carreira universitária. Por um lado, as possibilidades de investimento de Florestan Fernandes nessa carreira estão associadas às próprias chances de tirar algum tipo de rendimento material dessa atividade, ou seja, passa a atuar como assistente somente após a conclusão do curso superior, 
sendo que, a dedicação integral a essa atividade somente é possível depois da modificação da "carreira de assistente", pós-1947. Ao mesmo tempo, há um investimento constante na produção de artigos e resenhas, de modo a destacar-se pela dedicação ao trabalho intelectual em um contexto de afirmação das ciências sociais no Brasil. No entanto, como indicado, a modificação da condição de aspirante a um posto, para ocupante efetivo desse, modifica, também, as modalidades de atuação. Anteriormente pautadas na adaptação e adesão as regras do jogo, ou seja, na inserção em relações de reciprocidade, posteriormente a atuação passa a ser fundada na constituição de um grupo e na retribuição de seus membros por meio do controle dos recursos atinentes a posição de catedrático. Igualmente, há uma intensificação da atuação junto aos de baixo. Nesse sentido, parece haver uma disposição, derivada de sua origem social, para a militância e o engajamento em movimentos sociais e para a utilização das ciências sociais na formação de atitudes cívicas e na constituição de uma consciência política definida em torno da compreensão dos direitos e dos deveres dos cidadãos (FERNANDES, 1977, p. 117).

No extremo oposto dessa posição, encontra-se o trajeto de Fernando Henrique Cardoso. Com origem social muito elevada e proveniente de uma família historicamente ligada ao exercício do poder político e militar no Brasil, as condições de constituição de uma carreira universitária são outras e, inclusive, essa assume outras conotações. Com passagem por escolas particulares e com a disponibilidade de acesso ao estudo de línguas, através de professores particulares (GARCIA Jr., 2004, p. 289), as condições de ingresso e de realização de um curso superior são outras. Do mesmo modo, pelas possibilidades de guardar uma independência com relação às determinações sociais, a atuação nas atividades da universidade ocorre de modo voluntário, participando, desde os primeiros anos do curso superior, de projetos desenvolvidos no âmbito da FFCL e do IA. Ao mesmo tempo, o conjunto de posições políticas ocupadas por membros de sua família, concomitantemente ao período de constituição de sua 
carreira universitária, favorece o trânsito entre diversas esferas de poder e o acesso a inúmeros recursos, tanto privados como públicos. Esse conjunto de relações simétricas estabelecidas com diversos agentes em espaços sociais distintos, e o conjunto de relações assimétricas estabelecidas com outros agentes em condições sociais mais baixas, são relativamente independentes dos postos ocupados na universidade, podendo ou não mesclar-se a eles. A condição socialmente dominante facilita, também, uma circulação nacional e internacional que permite acumular vínculos com organizações e centros de produção cultural. Ao que tudo indica, essa circulação por dentro das esferas de poder favorece uma concepção dos usos das ciências sociais como auxiliares na administração e uma atuação no sentido de conciliação de interesses, e de não ruptura.

Com base nessa exposição, ficam relativamente indicados os efeitos das origens sociais nas modalidades de investimentos e de constituição de carreiras universitárias e, particularmente, as estratégias desigualmente acionadas (CHARLE, 1987, p. 225) de acordo com as chances de acesso a determinados recursos. Igualmente, estão em pauta as diferentes expectativas de retribuição relativamente a determinadas posições no trajeto e as respectivas origens sociais, apontando para a necessidade de exames mais detalhados sobre as relações disso com as estratégias e modos de reprodução e legitimação da dominação em espaços e polos de estruturação social.

\section{Referências bibliográficas}

ABREU, Alzira Alves de et al. (coord.). Dicionário Histórico-Biográfico Brasileiro: pós - 1930. Rio de Janeiro: FGV/CPDOC, 2001.

ABRUCIO, Fernando. et al. Conversas com Sociólogos Brasileiros. São Paulo: Editora 34, 2006. 
ALMEIDA, Maria Hermínia T. Dilemas da Institucionalização das Ciências Sociais no Rio de Janeiro. In: MICELI, Sérgio (org). História das Ciências Sociais no Brasil. São Paulo: Vértice, 1989. p. 188-216.

ARRUDA, Maria Arminda do Nascimento. Modernidade do Possível: Cientistas e Ciências Sociais em minas Gerais. In: MICELI, Sérgio (org). História das Ciências Sociais no Brasil. São Paulo: Vértice, 1989. p. 234-315.

. Pensamento brasileiro e sociologia da cultura: questões de interpretação. Tempo Social - Revista de sociologia da USP, v. 16, n. 1, p. 107-118, 2004.

ARRUDA, Maria Arminda N.; GARCIA, Sylvia G. Florestan Fernandes: mestre da sociologia moderna. Brasília: Paralelo 15, 2003.

ASSOCIAÇÃO DOS DOCENTES DA USP. 0 Controle Ideológico da USP (19641978). São Paulo: ADUSP, 2004.

BADIE, Bertrand y HERMET, Guy. Política Comparada. México: Fondo de Cultura Económica, 1993.

BARREIRA, César. (org) A sociologia no tempo. Memória, imaginação e utopia. São Paulo: Cortez, 2003.

BASTOS, Elide Rugai. et al., Conversas com Sociólogos Brasileiros: Retórica e Teoria na História do Pensamento Sociológico do Brasil. São Paulo: FGVEAESP/GVPesquisa, 2008. Relatório de pesquisa n. 11/2008.

BORDIGNON, Rodrigo da Rosa. Ascensão e hierarquização "profissional" nas Ciências Sociais: um estudo a partir do caso da "Escola Sociológica Paulista". Trabalho de Conclusão de Curso apresentado ao Curso de Ciências Sociais - UFRGS. Porto Alegre, 2010.

BOTELHO, André; LUHERTA, Milton. Interpretações do Brasil, pensamento social e cultura política: tópicos de uma necessária agenda de investigação. Perspectivas, 28, p. 7-15, 2005.

BOURDIEU, Pierre. La représentation de la position sociale. Actes de la Recherche en Sciences Sociales, v. 52, no 1, p. 14-15, 1984.

The forms of capital. In: RICHARDSON, J. E. (ed.). Handbook of Theory of Research for the Sociology for Education. New York: Greenwood Press, 1986. p. 241-258.

. Lições de aula: Aula inaugural proferida no Collège de France em 23 de abril de 1982. São Paulo: Ática, 1994.

Razões práticas: sobre a teoria da ação. São Paulo: Papirus,

1996. 
O capital social - notas provisórias. Os três estados do capital cultural. Futuro de classe e causalidade do provável. 0 diploma e o cargo: relações entre o sistema de produção e o sistema de reprodução. Classificação, desclassificação, reclassificação. In: CATANI, Afrânio. NOGUEIRA, Maria Alice. (orgs). Escritos de Educação: Pierre Bourdieu. Rio de Janeiro: Vozes, 2007. p. 65-184.

0 senso prático. Rio de Janeiro: Vozes, 2009.

BRANDÃO, Gildo Marçal. Linhagens do pensamento político brasileiro. DADOS - Revista de Ciências Sociais, v. 48, n. 2, p. 231-269, 2005.

CÂNDIDO, Antônio. Entrevista com Antônio Cândido. Revista Brasileira de Ciências Sociais, v. 16, n. 47, p. 5-30, 2001.

. 0 Jovem Florestan. Estudos Avançados, 10 (26), p. 11-15, 1996. . Octávio Ianni: Um homem justo. Revista de Crítica Literária Latino-Americana, ano XXXI, n. 61, p. 203-205, 2005.

CARDOSO, Fernando Henrique. Educação e desenvolvimento econômico. Revista Brasiliense, 17, p. 70-81, 1958.

A utopia do viável: Trajetória intelectual de Fernando Henrique Cardoso. Brasília: Presidência da República, 1995.

A arte da política: histórias que vivi. Rio de Janeiro: Civilização Brasileira, 2006. Disponível em: < http://www.fae.ufmg.br/objuventude/ upload/producoes/a496dba7ea0aa5271b20631df1551683.teste.pdf >. Acesso em: Junho/2009.

O sociólogo e o político. Entrevista concedida a Bernando Sorj e Sérgio Fausto. 2008. Disponível em: <http://www.bernardosorj.com/Novidades/0\%20sociologo $\% 20 \mathrm{e} \% 20 \mathrm{o} \% 20$ politico $\% 20$ PORT. pdf_07_06_2009_17_05_02.pdf>

CERQUEIRA, Laurez. Florestan Fernandes: vida e obra. São Paulo: Expressão Popular, 2004.

CHARLE, Christophe. Les Élites de la République (1880 - 1900). Paris: Fayard, 1987.

COLLOVALD, Annie. Identité(s) stratégique(s). Actes de la Recherche en Sciences Sociales, v. 73, n. 1, p. 29-40, 1988.

Jacques Chirac : un leader sans ressources. Revue Française de Science Politique, v. 40, n. 6, p. 880-901, 1990.

CONINCK, Frédéric, GODARD, Francis. L’approche biographique à l'épreuve de l'interprétation. Les formes temporelles de la causalité. Revue française de sociologie, 31-1, p. 23-53, 1990. 
CORADINI, Odaci Luiz. Recursos de origem, Investimentos e Expectativas de Retribuição na Militância do MST. Espacio Abierto. Cuaderno Venezolano de Sociología, v. 19, n. 3, p. 445-473, 2010.

. As missões da "cultura" e da "política": confrontos e reconversões de elites culturais e políticas no Rio Grande do Sul (1920-1960). Estudos Históricos, n. 32, p. 125-144, 2003.

. A Formação e a Inserção Profissional dos Professores de Ciências Sociais no Rio Grande do Sul. In: CANEDO, Letícia B. et al (orgs). Circulação internacional e formação intelectual das elites brasileiras. Campinas/SP: Editora da UNICAMP, 2004. p. 213-240.

L’Enseignement Universitaire de Théologie, les Rapports Centre/Péripherie et les Usages des Sciences Humaines et Sociales. Cahiers de la Recherche sur l'Éducation et les Savoirs, v. 2, p. 93-116, 2009.

CUNHA, Mário Wagner Vieira da. Entrevista com Mário Wagner Vieira da Cunha. Tempo Social - Revista de Sociologia da USP, São Paulo, v.20, n. 2, p. 259-301, 2008.

DAMAMME, Dominique. Grandes illusions et récits de vie. Politix : Revue des sciences sociales du politique, v. 7, n. 27, p. 183-188, 1994.

DEZALAY, Y. Les courtiers de l'international. Actes de la Recherche en Sciences Sociales, n. 151/152, p. 5-35, 2004.

FERNANDES, Florestan. Ensaios de sociologia geral e aplicada. São Paulo: Livraria Pioneira Editora, 1971.

tores, 1975.

A Revolução Burguesa no Brasil. Rio de Janeiro: Zahar EdiZahar Editores, 1976.

A Sociologia numa era de Revolução Social. Rio de Janeiro: A Sociologia no Brasil. Rio de Janeiro: Vozes, 1977.

A condição de sociólogo. São Paulo: Hucitec, 1978.

. A questão da USP. São Paulo: Brasiliense, 1984.

. Entrevista. Entrevista concedida a Paulo de Tarso Venceslau. 1991. Disponível em: <http://static.recantodasletras.com.br/arquivos/411323.pdf>

. Entrevista. In: ARRUDA, Maria Arminda N.; GARCIA, Sylvia G. Florestan Fernandes: mestre da sociologia moderna. Brasília: Paralelo 15, 2003. 
FERNANDES JUNIOR, Florestan; FERNANDES, Heloísa R. Tudo na vida é sério, mas nada é definitivo. Revista da Adusp, p. 22-27, outubro/1995.

FREITAG, Barbara. Florestan Fernandes por ele mesmo. Estudos Avançados, 10 (26), p. 129-172, 1996.

GARCIA Jr. Afrânio. A dependência da política: Fernando Henrique Cardoso e a sociologia no Brasil. Tempo Social - Revista de Sociologia da USP, v. 16, n 1, p. 285-300, 2004.

GAXIE, Daniel. Rétributions du militantisme et paradoxes de l'action collective. Swiss Political Science Review, 11 (1), p. 157-188, 2005.

GRIJÓ, Luiz Alberto. Ensino Jurídico e Política Partidária no Brasil: A Faculdade de Direito de Porto Alegre (1900 - 1937). Tese de Doutorado apresentada ao Programa de Pós-Graduação em História/ UFF. Rio de Janeiro, 2005.

. Biografia, para quê? In : CORADINI, Odaci, L. (org). Estudos de grupos dirigentes no Rio Grande do Sul: contribuições recentes. Porto Alegre: Editora da UFRGS, 2008, p. 85-102.

IANNI, Octávio. Tendências do pensamento brasileiro. Tempo Social - Revista de Sociologia da USP, 12(2), p. 55-74, 2000.

JACKSON, Luiz Carlos. A sociologia paulista nas revistas especializadas (1940 - 1965). Tempo Social: Revista de Sociologia da USP, v.16, n.1, p. 263-283, 2004.

Tensões e disputas na sociologia paulista (1940-1970). Revista

Brasileira de Ciências Sociais, v. 22 n. 65, p. 33-49, 2007a.

. Gerações pioneiras da sociologia paulista (1934 - 1969). Tempo

Social - Revista de Sociologia da USP, v. 19, n. 1, p. 115-130, 2007b.

KANTOR, Iris; MACIEL, Débora A.; SIMÕES, Júlio Assis. A Escola Livre de Sociologia e Política: anos de formação 1933-1953. São Paulo: Sociologia e Política, 2009.

LIEDKE FILHO, Enno D. A sociologia no Brasil : história, teorias e desafios. Sociologias, ano 7, n.14, p. 376-437, 2005.

LIMONGI, Fernando. Mentores e Clientelas da Universidade de São Paulo. In: MICELI, Sérgio (org). História das Ciências Sociais no Brasil. São Paulo: Vértice, 1989a. p. 111-187.

A Escola Livre de Sociologia e Política em São Paulo. In: MICE-

LI, Sérgio (org). História das Ciências Sociais no Brasil. São Paulo: Vértice, 1989b. p. 217-233. 
LIMOEIRO CARDOSO, Miriam. Em memória de Florestan Fernandes. Estudos Avançados, 9 (25), p. 7-10, 1995.

MAIO, Marcos Chor. O projeto UNESCO e a agenda das ciências sociais no Brasil dos anos 40 e 50. Revista Brasileira de Ciências Sociais, v. 14, n. 41, p. 141158, 1999.

MARTINS, Luciano. A gênese de uma intelligentsia: os intelectuais e a política no Brasil (1920 a 1940). Revista Brasileira de Ciências Sociais, v. 2, n. 4, 1987.

MASSI, Fernanda. Franceses e Norte-Americanos nas Ciências Sociais Brasileiras (1930-1960). In: MICELI, Sérgio (org). História das Ciências Sociais no Brasil. São Paulo: Vértice, 1989. p. 410-459.

MICELI, Sérgio. Os intelectuais e a classe dirigente no Brasil (1920-1940). Rio de Janeiro: DIFEL, 1979.

Vértice, 1989.

(org). História das Ciências Sociais no Brasil. V.1. São Paulo: (org). História das Ciências Sociais no Brasil. V.2. São Paulo: Vértice, 1995

Intelectuais à Brasileira. São Paulo: Companhia da Letras, 1999.

NEVEU, Eric. Le sceptre, les masques et la plume. Mots, v. 32, n. 1, p. 7-27, 1992.

PÉCAUT, Daniel. Os intelectuais e a política no Brasil: entre o povo e a nação. São Paulo: Ática, 1990.

PENNEF, Jean. Les grandes tendances de l'usage des biographies dans la sociologie française. Politix : Revue des sciences sociales du politique, v. 7, n. 27, p. 25-31, 1994.

POLLAK, Michel. La gestion de l'indicible. Actes de la Recherche en Sciences Sociales, v. 62-63, p. 30-53, 1986.

. Memória, esquecimento, silêncio. Estudos históricos. Rio de Janeiro, v. 2. n. 3, p. 3-13, 1989.

PONTES, Heloísa. Círculos de intelectuais e experiência social. Revista Brasileira de Ciências Sociais, 12, 34, 1997.

PULICI, Carolina. De como o sociólogo brasileiro deve praticar seu oficio: as cátedras de sociologia na USP de 1954 a 1969. Perspectivas, São Paulo, v. 31, p. 97-120, 2007.

SACCHETTA, Vladimir. Sumário do Curriculum de Florestan Fernandes. Estudos Avançados, 10 (26), p. 55-62, 1995. 
SAINT MARTIN, Monique de. À propos d'une rencontre entre chercheurs : Sciences sociales et politique au Brésil. Actes de la Recherche en Sciences Sociales, n. 71/72, p. 129-134, 1988.

SCHWARTZMAN, Simon. Um espaço para a ciência: a formação da comunidade científica no Brasil. Brasília: Ministério da Ciência e Tecnologia / Centro de Estudos Estratégicos, 2001.

SOARES, Eliane Veras. Florestan Fernandes: o militante solitário. São Paulo: Cortez, 1997.

SORJ, Bernardo. A construção intelectual do Brasil contemporâneo: da resistência a ditadura ao governo FHC. Rio de Janeiro: Jorge Zahar Editor, 2001.

SOUZA MARTINS, José de. Florestan: sociologia e consciência social no Brasil. São Paulo: Edusp, 1998.

TRINDADE, Hélgio. Ciências sociais no Brasil em perspectiva: fundação, consolidação e institucionalização. In: As ciências sociais na América Latina em perspectiva comparada: 1930-2005. Porto Alegre: Editora da UFRGS, 2006. p. 73-177.

Institucionalização e internacionalização das ciências sociais na América Latina em questão. In: CANEDO, Letícia B. et al (orgs). Circulação internacional e formação intelectual das elites brasileiras. Campinas/SP: Editora da UNICAMP, 2004. p. 144-167. 